\title{
Mutations of p53 gene and SV40 sequences in asbestos associated and non-asbestos-associated mesotheliomas
}

\author{
Frederick G Mayall, Gregory Jacobson, Richard Wilkins
}

Department of Pathology, Waikato Hospital, Private Bag 3200, Hamilton, New

Zealand

F G Mayall

Department of Biology, Waikato University

G Jacobson

$\mathrm{R}$ Wilkins

Correspondence to: Dr Mayall.

email: mayallf@hwl.co.nz

Accepted for publication 27 November 1998

\begin{abstract}
Aim-To examine mesotheliomas for a possible relation between p53 immunostaining, p53 gene mutation, simian virus 40 (SV40), and asbestos exposure.

Methods-Paraffin sections from 11 mesotheliomas were used for p53 immunostaining and also to extract DNA. This was analysed for the presence of mutations in exons 5 to 8 of the p53 gene using a "cold" single strand conformational polymorphism method, together with sequencing. The DNA from the paraffin sections was also used to search for SV40 sequences. A 105 base pair segment at the $3^{\prime}$ of the SV40 large $T$ antigen (Tag) was targeted and any PCR amplification products were sequenced to confirm that they were of SV40 origin. EDAX electron microscopic differential mineral fibre counts were performed on dried lung tissue at a specialist referral centre.
\end{abstract}

Results-The fibre counts showed that seven of the mesotheliomas were associated with abnormally high asbestos exposure. Of these, two showed p53 immunostaining, none showed p53 gene mutation, and five showed SV40. Of the four other mesotheliomas, three showed p53 immunostaining, one showed a (silent) p53 mutation, and none showed SV40. The difference in frequency of SV40 detection was significant at the $p<0.05$ level.

Conclusions-Immunostaining for the p53 gene was relatively common but p53 mutations were rare in this series. SV40 virus sequence was detected in five of seven asbestos associated mesotheliomas but in none of the non-asbestos-associated mesotheliomas. This suggests there may be a synergistic interaction between as-

mas. A study with a larger number of cases is needed to investigate these observations further.

(F Clin Pathol 1999;52:291-293)

Keywords: mesothelioma; $\mathrm{p} 53$ gene; simian virus 40 ; single strand conformational polymorphism

Immunostaining of p53 in tumours is usually the result of mutation of the p53 gene or dysfunction of the p53 protein. Such p53 immunostaining is common in mesotheliomas, but p53 gene mutations are rare. ${ }^{12}$ In 1993 it was found that the injection of simian virus 40 (SV40) into the serous cavities of hamsters caused them to develop mesotheliomas. ${ }^{3} \mathrm{Re}-$ cently it has been shown that p53 immunostaining in human mesotheliomas may be related to the formation by $\mathrm{p} 53$ protein of an inactivating complex with SV40 large $T$ antigen (Tag). ${ }^{4}$ Tag also seems to interact with the retinoblastoma proteins $\mathrm{pRb}, \mathrm{p} 107$, and $\mathrm{pRb} 2 / \mathrm{p} 130 .^{5}$

Between $70 \%$ and $85 \%$ of mesotheliomas are associated with asbestos exposure. Asbestos has been shown to promote the transfection of mesothelial cell cultures by SV40 and picorna viruses. ${ }^{67}$ In addition it appears that SV40 transfected cells have an altered sensitivity to the toxicity of some forms of asbestos in vitro. ${ }^{8}$

The coincidence of SV40 and asbestos in the pathology of mesothelioma raises the possibility that the two might act synergistically in promoting malignant transformation in human mesothelium. Alternatively, SV40 might be more important in the development of nonasbestos-associated than of asbestos associated mesotheliomas. Our aim in this study was to examine mesotheliomas for a possible relation between p53 immunostaining, p53 gene mutation, SV40, and asbestos exposure.
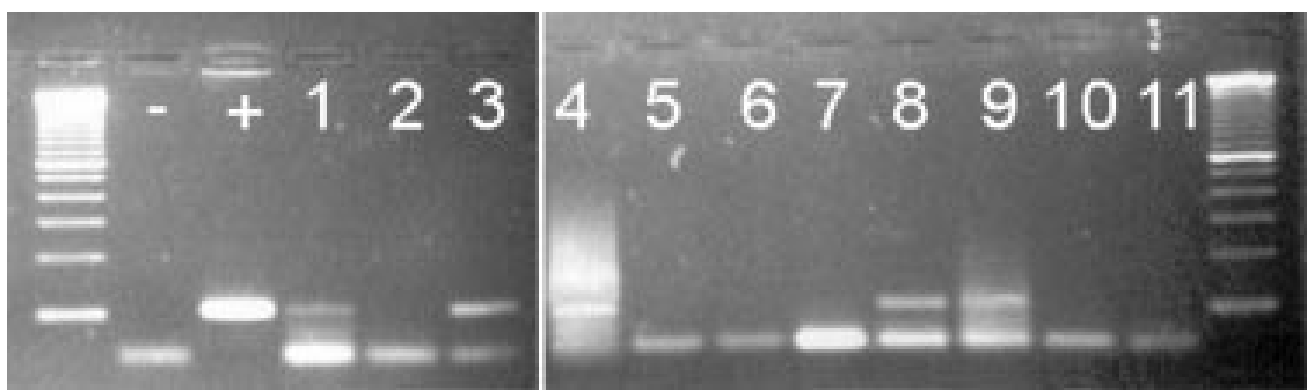

Figure 1 The PCR products targeting a sequence corresponding to the 3' end of the SV40 virus Tag gene in 11 mesotheliomas. Cases 1, 3, 4, 8, and 9 show positive bands consistent with the $105 \mathrm{bp}$ SV40 target. Dye termination sequencing confirmed this. 
Table 1 p53 Immunostaining, p53 gene mutations, and simian virus 40 (SV40) detection in mesotheliomas and its relation to the lung asbestos fibre count

\begin{tabular}{|c|c|c|c|c|c|c|c|c|}
\hline \multirow[b]{2}{*}{ Case } & \multirow[b]{2}{*}{ p53 IHC } & \multirow[b]{2}{*}{ p53 mutation } & \multirow[b]{2}{*}{ SV40 } & \multicolumn{4}{|c|}{$\begin{array}{l}\text { Transmission electron microscopic differential mineral fibre count } \\
\text { (million/g dried lung) } \dagger\end{array}$} & \multirow[b]{2}{*}{ Asbestos associated } \\
\hline & & & & Crocidolite & Amosite & Tremolite & Chrysolite & \\
\hline 3 & - & - & + & 7 & 44.2 & 0 & 0 & Yes \\
\hline 4 & - & - & + & 19.5 & 0.7 & 0.3 & 2.7 & Yes \\
\hline 5 & - & - & - & 0.6 & 2.4 & 0.6 & 4.1 & Yes \\
\hline 8 & + & - & + & 2.4 & 0 & 0 & 0 & Yes \\
\hline 9 & - & - & + & 1.6 & 2.5 & 0 & 4.4 & Yes \\
\hline 10 & + & - & - & 0.7 & 9.8 & 0 & 49.7 & Yes \\
\hline 11 & - & - & + & 1.7 & 2.1 & 0.4 & 1.3 & Yes \\
\hline 7 & + & + & - & 0.2 & 1.3 & 0.2 & 8.9 & Uncertain \\
\hline 1 & + & - & - & 0 & 0.4 & 0 & 0.1 & No \\
\hline 2 & - & - & - & 0.3 & 0 & 0 & 2.8 & No \\
\hline 6 & + & - & - & 0.4 & 0.6 & 0.1 & 0.5 & No \\
\hline
\end{tabular}

†Range for "unexposed" adults: crocidolite $0-1$, amosite $0-1$, tremolite $0-1$, chrysolite $0-50$.

IHC, immunohistochemistry.

In case 1 the fibre count is borderline and interpretation is uncertain; raised fibre count values are given in bold; no anthophyllite or erionite was detected in any of the cases.

The p53 mutation in case 7 was GAT $>$ GAC at codon 148 . This mutation is silent.

\section{Methods}

Paraffin sections from 11 mesotheliomas were used for p53 immunostaining, as described previously. ${ }^{2}$ These sections were also used to extract DNA. ${ }^{9}$ This was analysed for the presence of mutations in exons 5 to 8 of the p53 gene using a "cold" single strand conformational polymorphism (SSCP) method, together with excision of abnormal bands, reamplification, and dye termination sequencing. ${ }^{9}$ EDAX electron microscopic differential mineral fibre counts were performed on samples of lung using a highly practised method at a specialist referral centre (The Environmental Lung Disease Research Group, Llandough Hospital, Penarth, South Glamorgan, UK). The method is based on that described by Pooley and Clark in $1979 .{ }^{10}$

The DNA extracted from the paraffin sections was also used to search for SV40 sequences. A 105 base pair (bp) segment at the $3^{\prime}$ of the SV40 large $\mathrm{T}$ antigen (Tag) was targeted by a PCR protocol described by De Luca et al in 1997. ${ }^{5}$ We used primers described by Bergsagel et al in 1992, named "SV.for3" and "SV.rev" for forward and reverse respectively. ${ }^{11}$ Briefly PCR was performed using a $50 \mu \mathrm{l}$ reaction volume with $1.5 \mathrm{mM}$ $\mathrm{MgCl}_{2}, 0.8 \mathrm{pM} / \mu \mathrm{l}$ of each of the primers, and $200 \mu \mathrm{M}$ deoxynucleotide triphosphate (dNTP).

Thermal cycling was performed by denaturation at $95^{\circ} \mathrm{C}$ for two minutes followed by cycling 45 times at $95^{\circ} \mathrm{C}$ for 30 seconds, at $53^{\circ} \mathrm{C}$ for one minute, and at $72^{\circ} \mathrm{C}$ for 30 seconds. This was followed by an extension at $72^{\circ} \mathrm{C}$ for five minutes.

The negative control contained Milli-Q water instead of a template, and SV40 DNA (Life Technologies) was used as template in the positive control. The PCR products, from both tumour samples and each of the controls were electrophoresed on a $2 \%$ TBE agarose gel and photographed over a ultraviolet light transilluminator. If a band corresponding to the 105 bp target fragment was observed (fig 1) then the amplification product was submitted for sequencing with fluorescent dichlororhodimine dye terminator chemistry on an ABI prism 377 automated DNA sequencer (Perkin
Elmer). The sequences were submitted to GenBank for a Blast-N search (http:// www.ncbi.nlm.nih.gov/BLAST/) for confirmation that they were of SV40 origin. The PCR was repeated and confirmed the results of the first attempt. We also used the same method with template DNA from 17 large bowel carcinomas, and all were negative.

\section{Results}

The results are presented in table 1 . In one case the association of the mesothelioma with asbestos was uncertain as the level of asbestos was only marginally raised. If we assume that this case was not asbestos associated then the probability of no difference existing between asbestos associated mesotheliomas and nonasbestos-associated mesotheliomas for p53 immunostaining was $\mathrm{p}=0.175$, for $\mathrm{p} 53$ gene mutation $p=0.417$, and for SV40 $p=0.045$ (Fisher's exact test). The products showing positivity for SV40 on agarose gel electrophoresis did sequence successfully to between 60 to 80 of the $105 \mathrm{bp}$ product length in both directions and these fragments were found to correspond exactly to the target SV40 sequence. The only p53 gene mutation was a silent one in case 7 .

\section{Discussion}

We found that p53 immunostaining was quite common in mesotheliomas, but p53 mutations were rare. This is in agreement with previous studies. $^{2412}$ The only tumour that had a (silent) p53 gene mutation was one that did not have a clear association with asbestos exposure and did not show SV40 virus sequence. The major point of interest in our results is that SV40 virus sequence could be detected in five of seven asbestos associated mesotheliomas but could not be found in any of the four other mesotheliomas. The difference was significant at the $\mathrm{p}<0.05$ level and suggests a possible synergistic interaction between asbestos and SV40 that is important in human mesotheliomas. Asbestos seems to promote transfection by SV40 and picorna viruses in cell cultures. Various synthetic and natural materials have been found to cause mesotheliomas when injected in to the pleural cavities of animals, but 
they do not seem to cause mesotheliomas if they are inhaled. ${ }^{13}$ A popular theory is that the oncogenicity of asbestos may not be caused by a unique interaction with mesothelial cells but by the particular ability of amphibole asbestos fibres to evade the lungs defences and reach the pleural surfaces.

In conclusion, we showed a higher frequency of SV40 virus sequence in asbestos associated mesotheliomas than in other mesotheliomas. Another study with a larger number of cases is needed to investigate this observation further.

We would like to thank Dr Allen Gibbs of Llandough Hospital, South Glamorgan, UK, and Dr Roger Marshall of The Department of Community Health, Auckland University, New Zealand, for their help in this study.

1 Mor O, Yaron P, Huszar M, et al. Absence of p53 mutations in malignant mesotheliomas. Am $\mathcal{f}$ Respir Cell Mol Biol 1997;16:9-13.

2 Mayall FG, Goddard H, Gibbs AR The frequency of p53 immunostaining in asbestos-associated mesotheliomas and non-asbestos-associated mesotheliomas. Histopathology 1993;22:383-6.

3 Cicala C, Pompetti F, Carbone M. SV40 induces mesotheliomas in hamsters. Am f Pathol 1993;142:1524-33.
4 Carbone M, Rizzo P, Grimley PM, et al. Simian virus-40 Carbone M, Rizzo P, Grimley PM, et al. Simian virus-40
large-T antigen binds p53 in human mesotheliomas. large-T antigen binds p53
Nature Med 1997;3:908-12.

5 De Luca A, Baldi A, Esposito V, et al. The retinoblastoma gene family $\mathrm{pRb} / \mathrm{p} 105, \mathrm{p} 107, \mathrm{pRb} 2 / \mathrm{p} 130$ and simian virus-40 large T-antigen in human mesotheliomas. Nature Med 1997;3:913-16.

6 Dubes GR, Mack LR. Asbestos-mediated transfection of mammalian cell cultures. In Vitro Cell Dev Biol 1988;24: 175-82.

7 Appel JD, Fasy TM, Kohtz DS, et al. Asbestos fibers mediate transformation of monkey cells by exogenous plasmid DNA. Proc Natl Acad Sci USA 1988;85:7670-4.

8 Gabrielson EW, Van der Meeren A, Reddel RR, et al. Human mesothelioma cells and asbestos-exposed mesothelial cells are selectively resistant to amosite toxicity: a possible mechanism for tumor promotion by asbestos. Carcinogenesis 1992;13:1359-63.

9 Mayall F, Jacobson G, Wilkins R, et al. Mutations of p53 gene can be detected in the plasma of patients with large bowel carcinoma. F Clin Pathol 1998;51:611-13.

10 Pooley FD, Clark NJ. Quantitative assessments of inorganic fibrous particulates in dust samples with an analytical transmission electron microscope. Ann Occup Hyg 1979; 22:253-71.

11 Bergsagel D, Finegold M, Butel JS, et al. DNA sequences similiar to those of simian virus 40 in ependymomas and choroid plexus tumours of childhood. N Engl F Med 1992; 326:988-93.

12 Mor O, Yaron P, Huszar M, et al. Absence of p53 mutations in malignant mesotheliomas. Am 7 Respir Cell Mol Biol in malignant

13 Wagner JC. Mineral fibres and mesothelioma. Thorax 1986; 41:161-6 